\title{
Renolith Appraisal on Lateritic Soils Along Oshogbo-Iwo Road in Southwest Nigeria
}

\author{
Quadri Ajibola Ibrahim ${ }^{1, ~ *, ~ O l a g b a y e ~ A k i n f o l a y a n ~ J a m e s ~}{ }^{2}$, Abdulhameed Mubaarak Itunuoluwa ${ }^{1}$ \\ ${ }^{1}$ Civil and Environmental Engineering Department, The Federal University of Technology, Akure, Nigeria \\ ${ }^{2}$ Precision Builders Nigeria Ltd., Algbaka Akure, Nigeria \\ Email Address: \\ aiquadri@futa.edu.ng (Q. A. Ibrahim) \\ ${ }^{*}$ Corresponding author
}

\section{To cite this article:}

Quadri Ajibola Ibrahim, Olagbaye Akinfolayan James, Abdulhameed Mubaarak Itunuoluwa. Renolith Appraisal on Lateritic Soils Along Oshogbo-Iwo Road in Southwest Nigeria. International Journal of Science and Qualitative Analysis. Vol. 4, No. 1, 2018, pp. 1-6. doi: $10.11648 /$ j.ijsqa.20180401.11

Received: December 21, 2017; Accepted: January 16, 2018; Published: February 2, 2018

\begin{abstract}
Soil stabilization using Renolith has proven to be an economical method of improving the properties of soil. Soil samples were collected from four different locations along Osogbo-Iwo Road, Osun State in Nigeria. Portland cement and Renolith were used for stabilization. The Atterberg test carried out before stabilization shows that the Liquid Limit of the four (4) samples ranged between $29 \%$ and $47.5 \%$, Plastic Limit between $18.81 \%$ and $35.98 \%$ while the Plasticity Index between $6.99 \%$ and $19.27 \%$. Three varied mix proportions i.e., (Cement was kept constant at 5\% while the Renolith was varied by $4 \%$, $10 \%$ cement constant, Renolith varied by $6 \%$ and $15 \%$ cement constant, Renolith varied by $8 \%$ ) of stabilizers were used to treat the samples. This was done by weight of the soil samples, to determine the effectiveness of using Renolith and also to determine the optimum concentration of cement-Renolith for stabilization. The tests carried out on the samples were Natural Moisture content, particle size analysis, hydrometer, Atterberg, California Bearing Ratio (CBR) and compressive strength. After stabilization, the properties of the soil were greatly improved as there was an increase in the CBR value of the samples up to $39.65 \%$ from $1.6 \%$. the use of $5 \%$ cement and $4 \%$ Renolith by weight of soil sample has been recommended as effective to improve the soil to a sub-base material.
\end{abstract}

Keywords: Renolith, Stabilization, Atterberg Limits, Lateritic Soil, California Bearing Ratio

\section{Introduction}

Engineering properties of soil are of great importance in the design of any civil engineering structure as all structures are founded on or in the soil. In a case where the soil properties are not satisfactory for supporting loads, suitable methods as alternative to enhancing its properties are employed [1]. Soil stabilization is one of such methods. Stabilizing the sub-grade and sub-base with an appropriate chemical stabilizer such as Quicklime, Portland Cement, Fly Ash, Bituminous materials or composites of chemical additives and polymers among others to increases the stiffness and reduces its expansion tendencies [2].

Several materials and methods have been employed to improved soil strength properties such as wood ash, lime, sawdust, waste materials, stone powder, cord reinforcement, waste beverage can among others. [3-10]. To stabilize soft subgrades, the most rampant approach is by excavating the undesirable soil first. Materials that are stronger, such as crushed rock then will be used to replace it. The cost involved for replacing the materials is quite unaffordable, thus it leads to various researches to find another method in order to counter this problem [12-13]. In order to establish an improved soil material with desired engineering properties, it is important for the soil to go through alteration for one or more properties. Either by adapting the mechanical or chemical method. This process is called soil stabilization [14]. The purpose of soil stabilization not only limited to enhance the load-bearing of the soil capacity [15-16] but also improve the shear strength, filter, drainage system [16], permeability, enhance soil resistance to the weathering process and traffic usage (ASTM, 1992) to meet specific engineering projects requirement [17].

Soil stabilization through mechanical and physical 
techniques can be done by decreasing the void rate through compacting $[14,18]$, the used of fibrous and geomaterials non-biodegradable reinforcement [18] or altering the grain size physically which also involves the particle size composition adjustment of the soil [14]. Through chemical technique, stabilization can be done by using chemical $[13,20]$, and emulsions since they work as compaction aids, binders, water repellants and as well as modifying the soil behaviour [20]. Reaction between chemical additives and particles of soil can bind the soil grains through strong network, thus produced soil with better quality compare to mechanical and physical techniques, since higher strength, durability and quality of soil can be achieved [14].

For the purpose of assessing the quality of the Renolith as a polymer additive and estimating its quality for stabilization, poor natural lateritic soil along Osogbo-Iwo road was examined. Renolith is an advanced cementitious polymer additive to cement that is soluble white milky viscous liquid. It is nontoxic and eco-friendly polymer which when combined with cement and in-situ soils, uniforms a concrete-like structure with the properties of flexibility, improved strength and enhance permeability properties of pavement. [1, 19]. Renolith appears to better control cracks and water penetration into those cracks to improve road base durability. All types of soils can be used exception organic soils. Granular soils are preferred in terms of easily pulverizing and mixing as a result it is more economically.

\section{Research Methodology}

Soil samples were collected from four different locations along Osogbo-Iwo Road. the additives used for stabilization and modification were Renolith and Portland cement which were purchased from the market and stored properly in the laboratory to prevent early hardening. Parts of the samples were subjected to tests without being treated with stabilizers to serve as control specimens.

The top soil was dug up and the samples were taken from a depth of $1.5 \mathrm{~m}$ below the natural ground level. The samples were subjected to laboratory tests such as natural moisture content, particle size analysis, hydrometer analysis, Atterberg limit,

compaction, California Bearing Ratio and Unconfined Compressive Strength. The samples were treated with the stabilizers by varying the percentage by mass of the soil. The variation was done in order to determine the optimum percentage that gives the most effective result. Atterberg limits, compaction, California Bearing Ratio and Unconfined Compressive Strength tests were repeated to determine the effect of the stabilizers (cement and Renolith) on the samples. All these tests were carried out according to [21], methods of tests for soils for Civil Engineering Purposes.

The wet method of grain size distribution test was adopted for this study because the samples contained a significant amount of fines. The portions of each sample passing sieve
No $200(75 \mu \mathrm{m})$ were subjected to hydrometer analysis. Liquid limit and plastic limit tests were carried out on the portions of each sample passing $425 \mu \mathrm{m}$ sized sieve. Standard compaction (Proctor) test was carried out to determine the optimum moisture content and maximum dry density of each of the samples. The strength of the soil samples to be used as base material for road is determined using the California Bearing Ratio test.

\section{Results and Discussions}

Presented in Tables 1 to 3 are the results of the tests carried out on the soil samples. Table 1 presents the test results for fine grained samples for natural moisture content, Atterberg, particle size distribution and compaction tests while Tables 2 and 3 present the classification of the soils based on American Association of State Highway and Transport Officials (AASHTO) and Unified Soil Classification System (USCS) classification systems.

It is seen in Table 1 that the average percentage of fine materials that passed through the $75 \mu \mathrm{m}$ was $36 \%$ which is not reliable. Hence, hydrometer test was carried out to further determine the amount of fine materials present. The results of the sieve and hydrometer analyses are as presented in Figures 1 to 4 these show the gradation of the soil particles from fine gravel to fine silt/clay materials. Furthermore, the results show that the soils are generally poor as sub-grade materials as there are presence of too much silt/clay contents as shown by the classification systems adopted. The Atterberg limits consisting of the liquid limit, the plastic limit and the plasticity index is generally high which implies that the four soil samples are inconsistent. Consequently, the moisture contents of the soils gave moderately high values except in sample 3. The maximum dry density of the control soil sample could not be adjudged see table 1. Hence, soil stabilization was done to improve the strength and constituency of the soils

\subsection{Compaction Test}

The compaction tests carried out on the control samples yielded the results of maximum dry density and optimum moisture content values presented in figures 5 to 8 . The maximum dry densities for the control samples 1 to 4 are $1800 \mathrm{Kg} / \mathrm{m}^{3}, 1658 \mathrm{Kg} / \mathrm{m}^{3}, 2200 \mathrm{Kg} / \mathrm{m}^{3}$, and $1550 \mathrm{Kg} / \mathrm{m}^{3}$ while the percentage moisture contents are $16.4 \%, 13.2 \%$, $9.5 \%$ and $16 \%$ respectively. The comparisons of the compaction test results of the treated samples and the control samples are presented in Figures 9 to 12 for the corresponding percentages of stabilizers used i.e., cement kept constant at 5\%,10\% and $15 \%$ while Renolith was varied at $4 \%, 6 \%$ and $8 \%$. There were more improvements in the dry densities of the samples when the Renolith was varied at $4 \%$ and cement kept constant at 5\%, also the moisture contents were drastically reduced compare to the untreated samples. Although the various variations used gave viable results, the 5\% cement constant and 4\% varied Renolith was considered the best fit. 
Table 1. Test Results for fine grained samples.

\begin{tabular}{|c|c|c|c|c|c|c|c|c|c|}
\hline \multirow[b]{2}{*}{ Samples } & \multirow{2}{*}{$\begin{array}{l}\text { Natural Moisture } \\
\text { Content }\end{array}$} & \multicolumn{3}{|c|}{ Particle Size Distribution } & \multicolumn{3}{|c|}{ Atterberg Limits } & \multicolumn{2}{|l|}{ Compaction } \\
\hline & & Passing No 200 (\%) & Silt Content (\%) & $\begin{array}{l}\text { Clay } \\
\text { Content (\%) }\end{array}$ & LL (\%) & PL (\%) & PI (\%) & $\operatorname{MDD}\left(\mathbf{k N} / \mathbf{m}^{3}\right)$ & OMC (\%) \\
\hline 1 & 8.5 & 36.00 & 28.23 & 20.25 & 35.0 & 28.01 & 6.99 & 1800 & 16.4 \\
\hline 2 & 4.0 & 36.26 & 32.32 & 25.63 & 44.0 & 24.73 & 19.27 & 1658 & 13.2 \\
\hline 3 & 1.1 & 36.25 & 27.44 & 28.22 & 29.0 & 18.81 & 10.19 & 2200 & 9.5 \\
\hline 4 & 4.4 & 36.00 & 33.08 & 19.33 & 47.5 & 35.98 & 11.52 & 1550 & 16.5 \\
\hline
\end{tabular}

Table 2. Summary of Atterberg limit and Soil Classification Analysis (AASHTO).

\begin{tabular}{llllllll}
\hline sample & (\%) passing sieve 200 & LL (\%) & PL (\%) & PI (\%) & Soil Group & Group Index & Rating as Sub-Grade Material \\
\hline 1 & 36 & 35 & 28.01 & 6.99 & A-4 & A-4 (0) & Fair \\
2 & 36.26 & 44 & 24.73 & 19.27 & A-7-6 & A-7-6 (2) & Poor \\
3 & 36.25 & 29 & 18.81 & 10.19 & A-4 & A4 (1) & Fair \\
4 & 36 & 47.5 & 35.98 & 11.52 & A-7-5 & A-7-5 (1) & Poor \\
\hline
\end{tabular}

Table 3. Summary of Atterberg limit and Soil Classification Analysis (USCS).

\begin{tabular}{lllllllll}
\hline Samples & $\begin{array}{l}\text { \% passing NO 200 } \\
\text { sieves }\end{array}$ & $\begin{array}{l}\text { \% passing No } \\
\text { 4 sieves }\end{array}$ & $\begin{array}{l}\text { Coarse } \\
\text { fraction }\end{array}$ & $\begin{array}{l}\text { Fraction } \\
\text { of gravel }\end{array}$ & $\begin{array}{l}\text { Fraction } \\
\text { of sand }\end{array}$ & $\begin{array}{l}\text { Atterberg plot on } \\
\text { plasticity chart }\end{array}$ & Group symbol & Group names \\
\hline 1 & 36 & 88.18 & 64 & 11.82 & 52.18 & below & ML & Sandy silt \\
2 & 36.26 & 84.3 & 63.74 & 15.7 & 48.04 & above & CL & Sandy clay with gravel \\
3 & 36.25 & 92.52 & 63.75 & 7.48 & 56.27 & above & CL & Sandy clay \\
4 & 36 & 77.02 & 64 & 22.98 & 1.02 & below & ML & Sandy silt with gravel \\
\hline
\end{tabular}

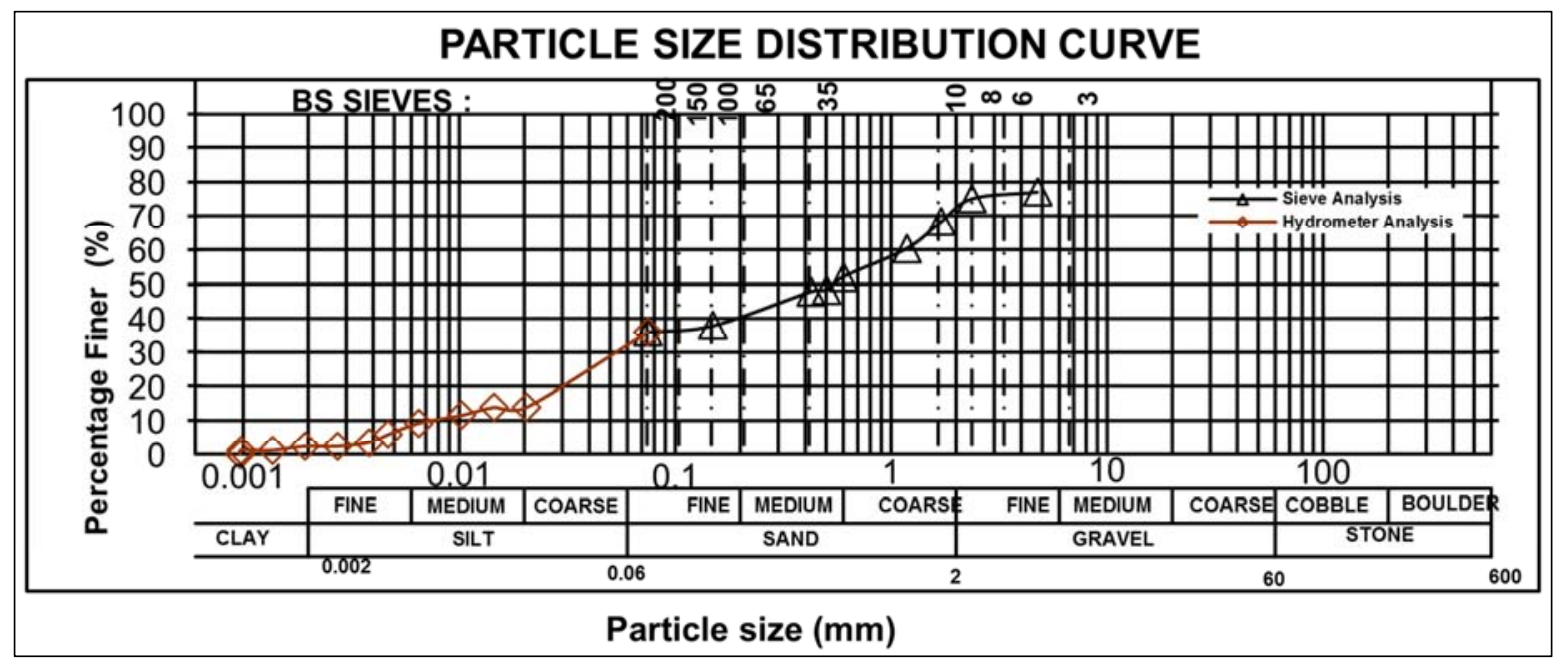

Figure 1. The Combined Sieve and Hydrometer Analysis chart for sample 1.

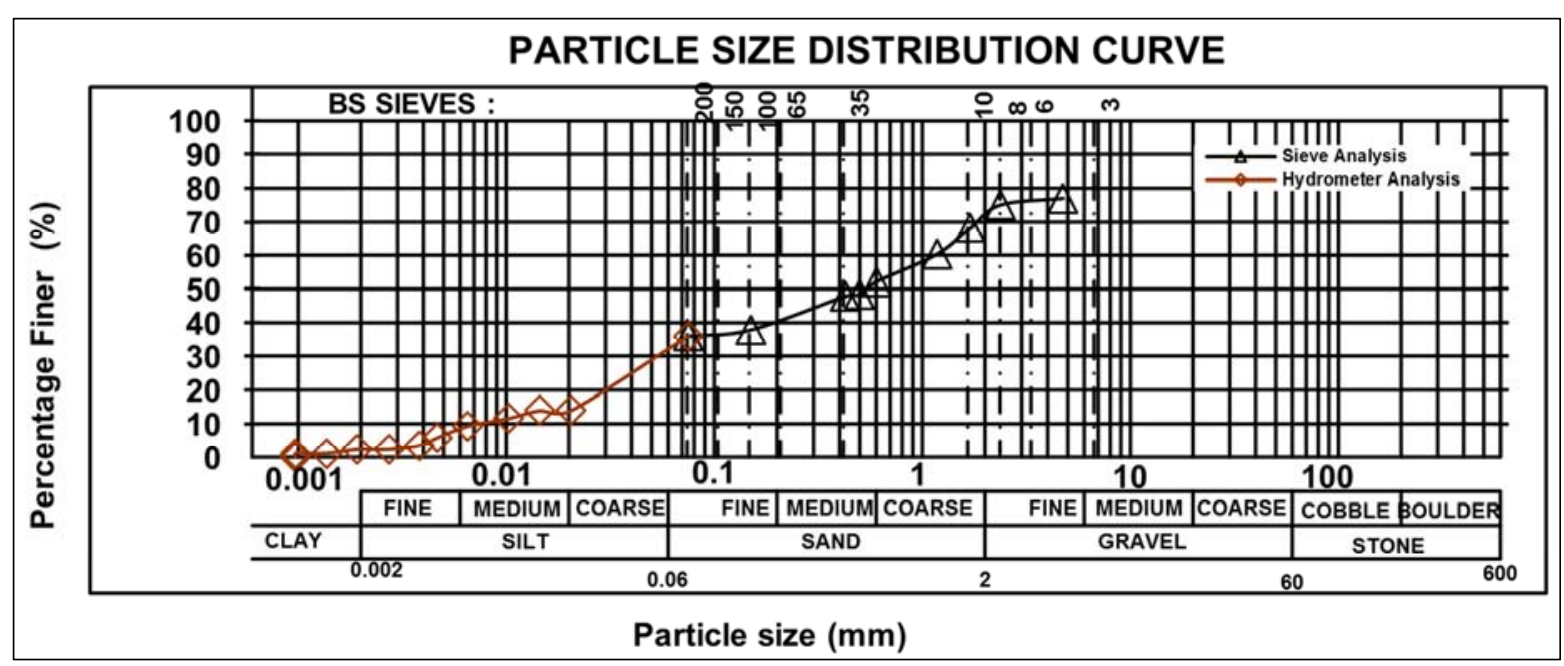

Figure 2. The Combined Sieve and Hydrometer Analysis chart for sample 2. 


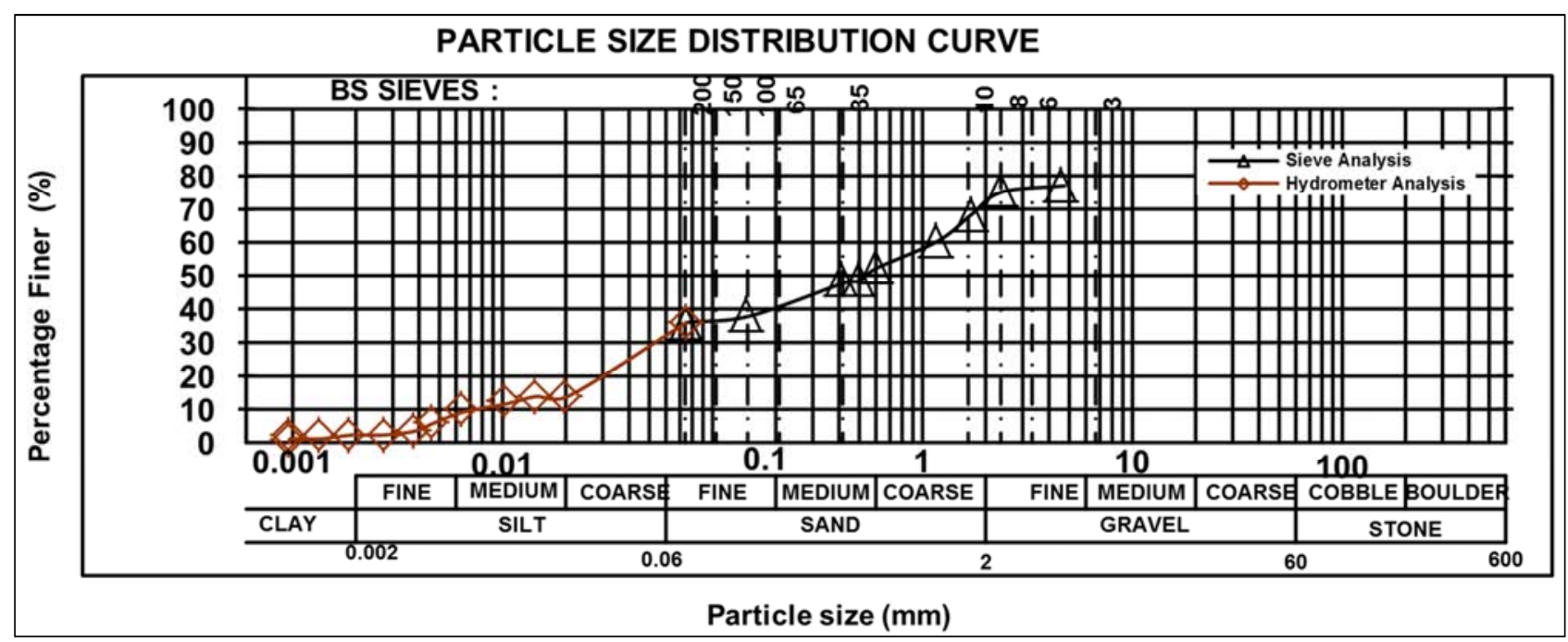

Figure 3. The Combined Sieve and Hydrometer Analysis chart for sample 3.

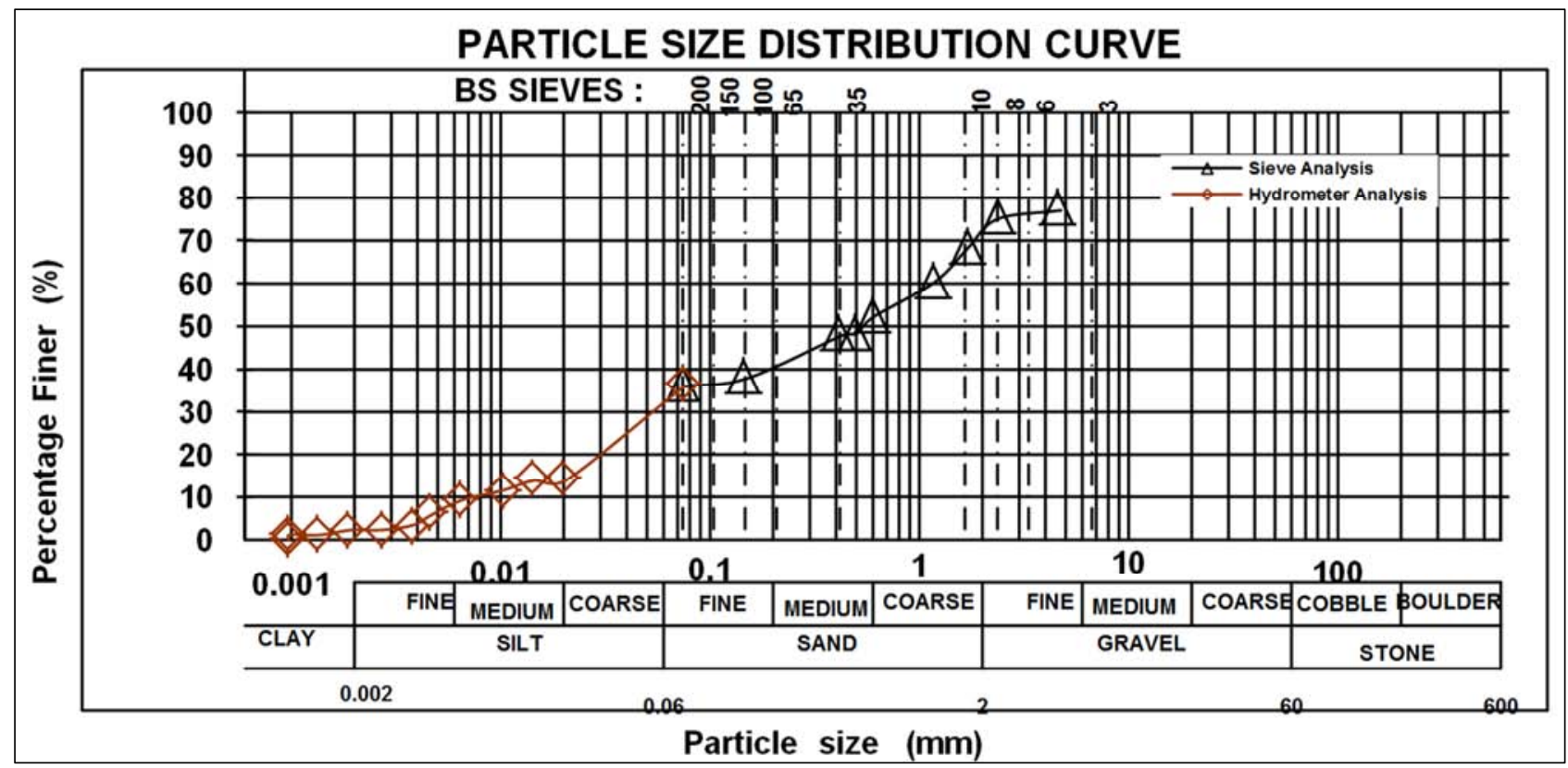

Figure 4. The Combined Sieve and Hydrometer Analysis chart for sample 4.

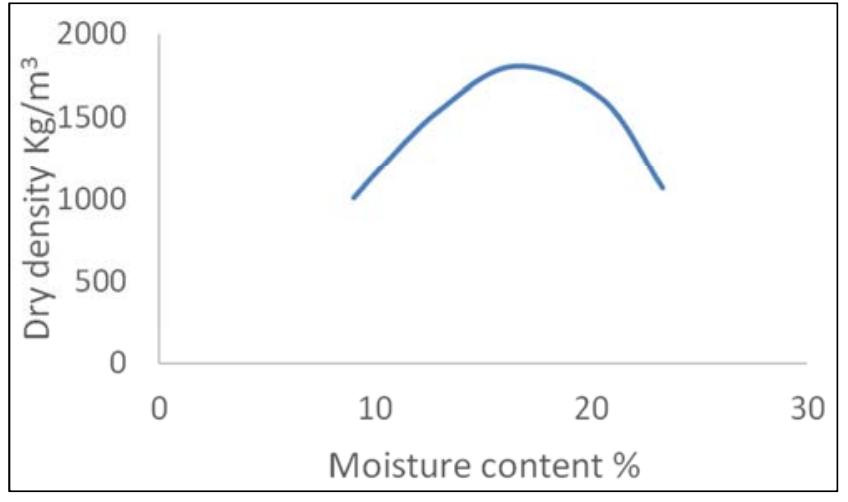

Figure 5. Standard Proctor Compaction for Control Sample 1.

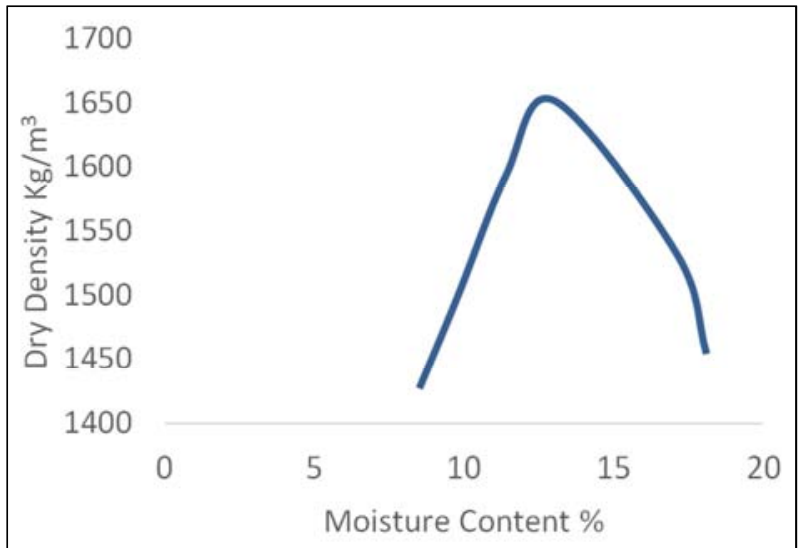

Figure 6. Standard Proctor Compaction for Control Sample 2. 


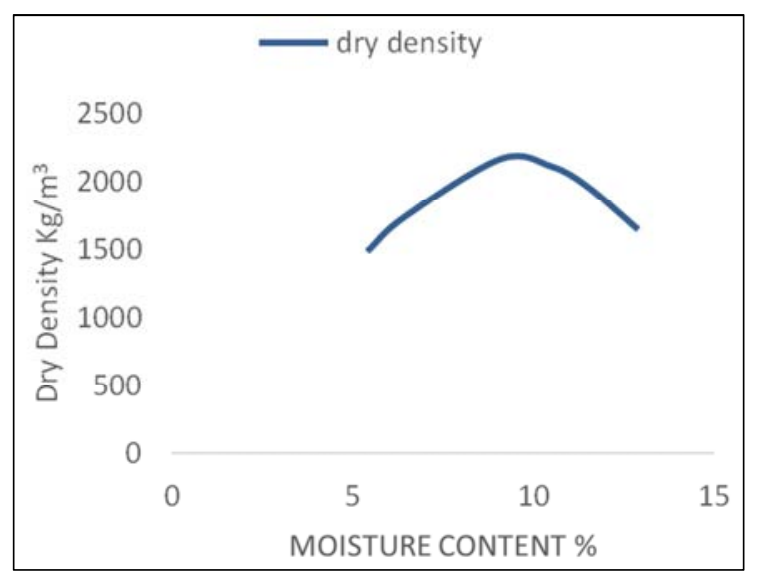

Figure 7. Standard Proctor Compaction for Control Sample 3.

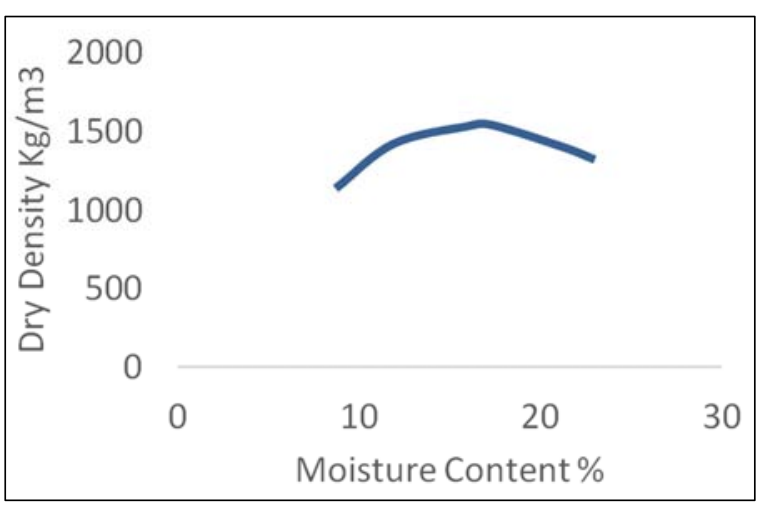

Figure 8. Standard Proctor Compaction for Control Sample 4.

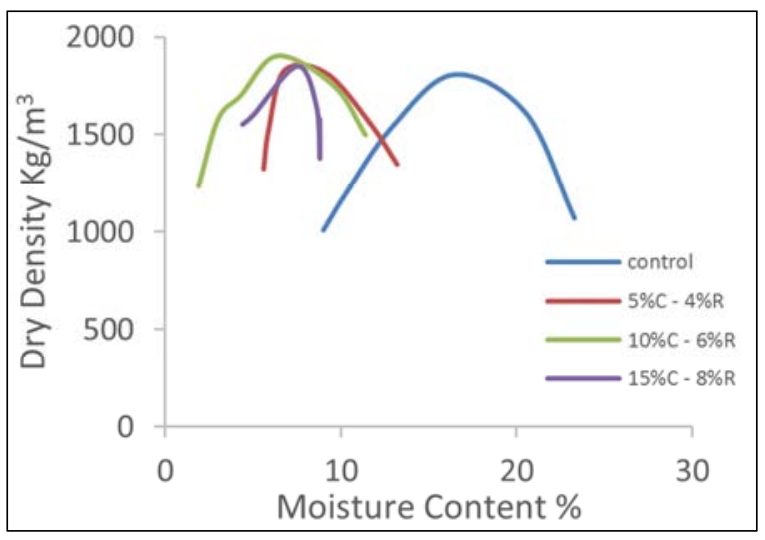

Figure 9. Comparison of MDD for sample 1.

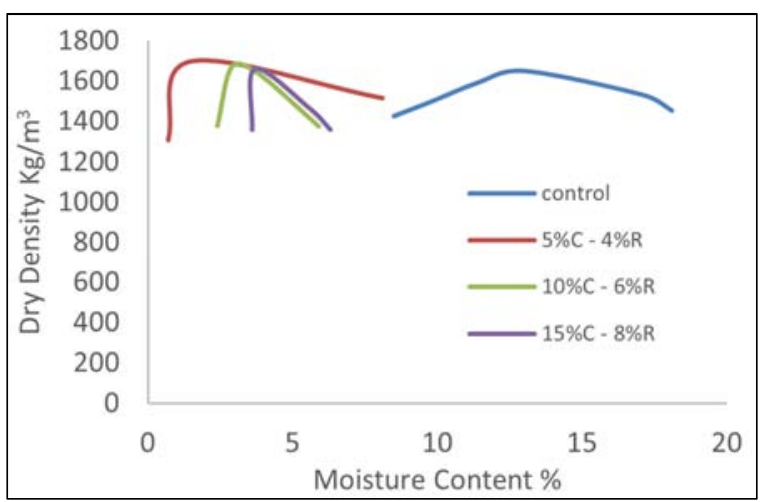

Figure 10. Comparison of MDD for sample 2.

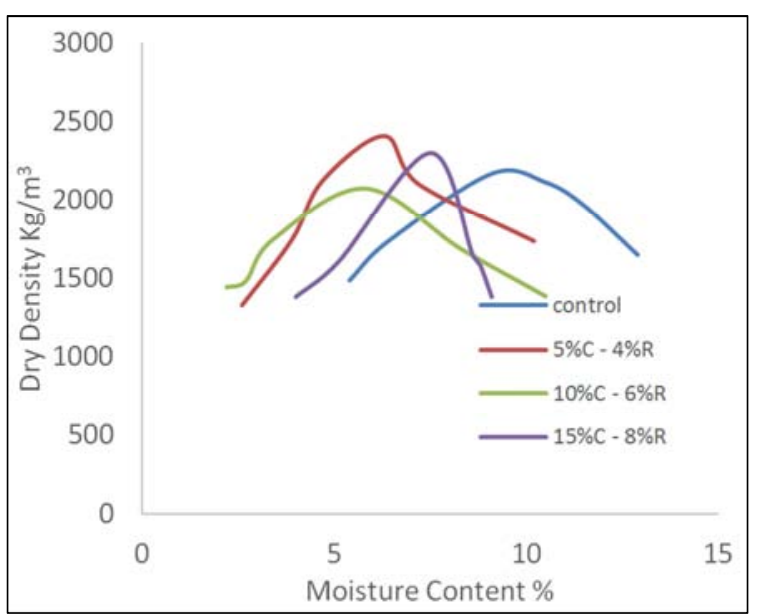

Figure 11. Comparison of MDD for sample 3.

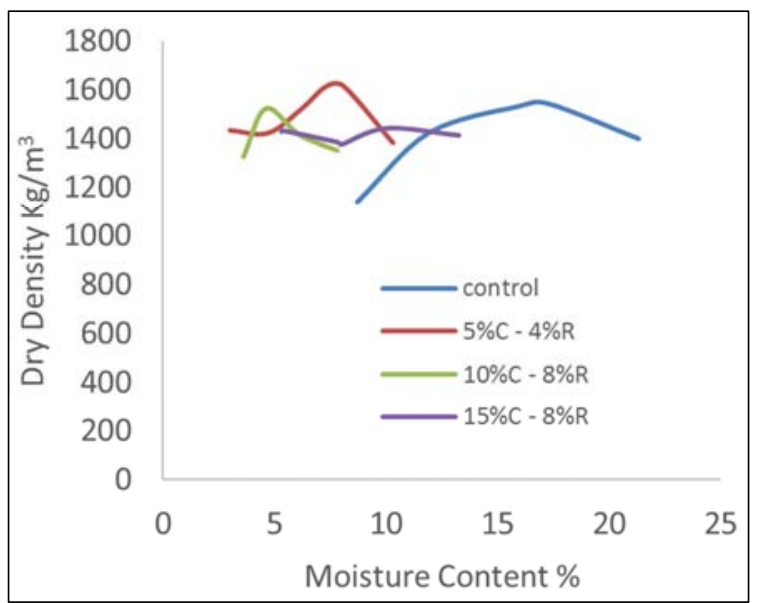

Figure 12. Comparison of MDD for sample 4.

\subsection{Strength and Durability}

Table 4 presents the results obtained from the California Bearing Ratio (CBR) for the control samples and also the treated samples. The results of the control samples are indication that none of them are suitable for sub-grade. When treated with cement-Renolith, dramatic improvement was seen as the results showed well improved percentage differences from the control samples.

Table 4. Percentage values of the CBR of control and treated samples with their percentage difference.

\begin{tabular}{|c|c|c|c|c|}
\hline Sample & 1 & 2 & 3 & 4 \\
\hline & (\%) & (\%) & (\%) & (\%) \\
\hline Control & 1.8 & 1.6 & 8.1 & 8.7 \\
\hline $\begin{array}{l}\text { Cement constant at } 5 \% \text { varying } \\
\text { Renolith by } 4 \%\end{array}$ & 14.04 & 27.65 & 22 & 14 \\
\hline $\begin{array}{l}\text { Cement constant at } 10 \% \text { varying } \\
\text { Renolith by } 6 \%\end{array}$ & 24 & 38.4 & 12 & 29.17 \\
\hline $\begin{array}{l}\text { Cement constant at } 15 \% \text { varying } \\
\text { Renolith by } 8 \%\end{array}$ & 26.3 & 27.2 & 22.2 & 14.4 \\
\hline
\end{tabular}

\section{Conclusion and Recommendations}

Based on CBR analysis, the amount of renolith that gave 
the best stabilization for sample 1 was the combination of $10 \%$ cement and $6 \%$ Renolith with maximum dry density of $1850 \mathrm{~kg} / \mathrm{m}^{3}$ with an optimum moisture content of $6.4 \%$ with CBR value of $26.3 \%$. For samples 2,3 and 4 , the combination that gave the best results was 5\% cement and 4\% Renolith which gave maximum dry densities of $1800 \mathrm{~kg} / \mathrm{m}^{3}, 2400$ $\mathrm{kg} / \mathrm{m}^{3}$ and $1620 \mathrm{~kg} / \mathrm{m}^{3}$ and optimum moisture content value of $8.5 \%, 6.2 \%$ and $6.9 \%$ respectively with $\mathrm{CBR}$ values of $39.65 \%, 22 \%$ and $30 \%$.

The test results have shown the beneficial effects of Renolith as a modifier to cement stabilized mixtures, improvement to strength and ability to reduce moisture content and capillary rise of water in soil.

The use of 5\% cement constant and varying Renolith at $4 \%$ by weight of soil is therefore recommended to improve and upgrade the soil to a sub-base material. Further research should be carried out on this work using percentages higher than the ones presented so as to determine the optimum amount of Renolith - cement that will give the best result.

\section{References}

[1] Owolabi T. A and Aderinola O. S (2014) 'An Assessment of Renolith on Cement-Stabilized poor Lateritic Soils' Sci-Afric Journal of Science issues, Research and Essays. Vol. 2 (5) Pp 222-237.

[2] O'Flaherty C. A (1974), Highway Engineering, $2^{\text {nd }}$ Edition Vol. 2 Edward Arnold Ltd. London.

[3] Aderinola O. S, Akingbonmire S. L and Quadri A. I (2017) "Geographical Information System (GIS) as A Search Tool for Geotechnical Information of Soil" International Journal of Scientific and Engineering Research. Vol. 8 issue 5. Pp822830 ISSN 2229-5518.

[4] Ankit S. N., Mohammed F., Devashish P. S., Rehanjot S. (2013), 'Soil Stabilization Using Lime' International Journal of Innovative Research in Science, Engineering and Technology. Vol. 2, issue 2 Pp 448453. ISSN: 2319-8753.

[5] Ashkan G. N., Siavash K., and Mohammad B. (2015) 'A Review of Using the Waste in Soil Stabilization' International Journal of Trend and Technology. Vol. 21, Issue1 Pp33-37. ISSN: 2231-5381.

[6] Butt, W. A., Gupta, K. and Jha, J. N. (2016) Strength behavior of clayey soil stabilized with saw dust ash' International Journal of Geo-Engineering. Vol. 7 issue 18, Pp2-9 ISSN: 2092-9196.

[7] Hanifi C., Fatih C., Mohammed O. A. Bizneb, Media O. A. Bizne 'Stabilization of Clay with Using Waste Beverage Can' World Multidisciplinary Civil Engineering-ArchitectureUrban Planning Symposium 2016 Vol. 161 Pp 595-599.

[8] Jafari, M. Esna-ashari. M. (2012), Effect of waste tire cord reinforcement on unconfined compressive strength of lime stabilized clayey soil under freeze-thaw condition. Cold Regions Science and Technology 82.

[9] Koteswara Rao. D, Pranav. P. R. T, Anusha. M (2011), Stabilization of Expansive Soil with Rice Husk Ash, Lime and Gypsum -An experimental Study IJEST, Vol. 3, No. 11.

[10] Okague C. O. (2007), Stabilization of Clay Using Wood Ash Journal of Materials in Civil Engineering. Vol. 19, issue11, Pp $7-18$.

[11] Roohbakhshan, A. Kalantari. A. (2013). Influence of lime and waste stone powder on the $\mathrm{pH}$ values and atterberg limits of clayey soil. ANNALS OF FACULTY ENGINEERING HUNEDOARA-International Journal of Engineering, pp. $177 \sim 180$.

[12] Aderinola, O. S, Oguntoyinbo, E. and Quadri A. I (2017) "Correlation of California Bearing Ratio Value of Clays with Soil Index And Compaction Characteristics" International Journal of Scientific Research and Innovative Technology. Pp 12-22 ISSN: 2313-3759, Vol. 4 No. 4.

[13] Fauzi, A., W. M. Nazmi, U. J. Fauzi, 2010. Subgrade Stabilization of Kuantan Clay Using Fly Ash and Bottom Ash. The 8th International Conference on Geotechnical and Transportation Engineering Geotropika 2010.

[14] ASTM Standards on Soil Stabilization with Admixtures, 2nd Edition. 1992. 126 pp.

[15] Bergado, D., L. Anderson, N. Miura, A. Balasubramaniam, 1996. Soft ground improvement: in lawland and other environment. New York: American Society of Civil Engineers.

[16] Prabakar, J., N. Dendorkar, R. K. Morchhale, 2004. Influence of fly ash on strength behavior of typical soils. Construction and Building Materials, 18: 263-276.

[17] Kolias, S., V. K. Rigopoulou, A. Karaholias, 2005. Stabilisation of clayey soils with high calcium fly ash and cement. Cement \& Concrete Composites, 27: 310-313.

[18] Olaniyan, O. S., Olaoye, R. A. Okeyinka, O. M. Olaniyan, D. B. (2011). Soil Stabilization Techniques Using Sodium Hydroxide Additives. Internal Journal of Civil \& Environment Engineering IJCEE-IJENS Vol: 11 No: 06.

[19] Jamal S. H and. Kumar P. S (2016) An Experimental Study on Renolith Treated Black Cotton Soil for Subgrade Pavements. International Journal of Science and Research (IJSR) Vol. 5, issue 11, Pp 1240-1244 ISSN (Online): 2319-7064.

[20] Graves, R. E., J. L. Eades, L. L. Smith, 1988. Strength Developed from Carbonate Cementation of Silica Carbonate Base Corse Materials. Transportation Research Record No. 1190.

[21] British Standard, 1377-2 (1990). Methods of Test for Soil for Civil Engineering Purposes-Compaction Related Tests. London. 